\title{
EFFECT OF SPECIMEN DIAMETER AND NOTCH DIAMETER ON THE FRACTURE TOUGHNESS OF AL7075 T6 ALLOY- AN EXPERIMENTAL APPROACH
}

\author{
Trimbak K. Todkari ${ }^{1}$, M. C. Swami ${ }^{2}$, P. S. Patil ${ }^{3}$ \\ ${ }^{\text {I}}$ M.E. Machine Design Student, Mechanical Department, M. S. Bidve Engineering College, Latur, Maharashtra, India \\ ${ }^{2}$ Assistant professor, Mechanical Department, M. S. Bidve Engineering College, Latur, Maharashtra, India \\ ${ }^{3}$ Assistant professor, Mechanical Department, G. N. D. Engineering College, Bidar, Karnataka, India.
}

\begin{abstract}
In this paper fracture toughness $\left(K_{I C}\right)$ of Al7075 T6 alloy has been determined by using circumferentially cracked round bar $(C C R B)$ specimen having three specimen diameters $(D) 12 \mathrm{~mm}, 10 \mathrm{~mm}, 8 \mathrm{~mm}$ and three notch diameters $(d) 10 \mathrm{~mm}, 8.3 \mathrm{~mm}, 6.7 \mathrm{~mm}$ respectively with constant D/d ratio as 1.2. The purpose of the study was to determine the effect specimen diameter and notch diameter on the fracture toughness of the Al7075 T6 alloy. The obtained fracture toughness results for different notch diameter are compared with ASTM standards. The result shows that the notch diameter has significant effect on the value of fracture toughness $\left(K_{I C}\right)$.
\end{abstract}

Key words: Al7075 T6 alloy, CCRB specimen, Fracture toughness, notched specimen.

\section{INTRODUCTION}

The need of high strength, low weight, and more corrosion resistant material is of current interest in the area of aerospace, marine etc. The Al 7075 T6 alloy material find wide applications in the different areas because of its excellent metallurgical properties. The Al 7075 T6 alloy is made more useful material with the characterization of material for fracture toughness. The determination of fracture toughness is based on the stress intensity factor $\left(\mathrm{K}_{\mathrm{IC}}\right)$ at the crack tip with subscript I denotes the fracture toughness test is performed in tensile mode and $\mathrm{C}$ denotes the critical value of stress intensity factor. When $\mathrm{K}$ attains critical value then crack propagation becomes unstable and result in fracture of components [1].

Normally $\mathrm{K}_{\mathrm{IC}}$ is determined by using compact-tension (CT) specimen or single edge notch bend (SENB) specimen or three point loaded bend specimens which are standardized by ASTM [14]. Also the standard test method for fracture toughness $\left(\mathrm{K}_{\mathrm{IC}}\right)$ of metallic material is given by the American Society for Testing and Material (ASTM) (designation E99) [2]. The ASTM E99 standard test method is to be one of the most accurate ways of measuring $\mathrm{K}_{\mathrm{IC}}$ of low ductility high strength alloys [3]. These methods are difficult and also the preparation of specimen. Notched round bar specimens have widely used for finding mechanical properties of materials [4-5]. The advantages of using circumferentially notched bars for fracture toughness testing can be summarized as follows:

- The plane strain condition can be obtained because the circumferential crack has no end in the plane stress region compared with the standard specimen geometries [6].
- Because of radial symmetry microstructure of the material along the circumferential area is completely uniform [7].

- $\quad$ Preparation of CCRB specimen is easy.

- Fracture toughness test is easy to perform.

In the previous studies, Bayram et al. [8] measured fracture toughness $\mathrm{K}_{\mathrm{IC}}$ of various steels and aluminum alloys with CCRB specimens and summarized that the experimentally measured fracture toughness values using CCRB specimens are accurate and reliable considering some correction factors.

Christopher D. Wilson and John D. Landes [9] used circumferentially notched round bars with finite notch root radii. They observed that the circumferential crack propagates radially inwards in tensile loading unlike unique crack propagation towards one direction in case of CT or SENB specimens.

Wang Chang [10] determined the plane strain fracture toughness $\left(\mathrm{K}_{\mathrm{IC}}\right)$ by single cylindrical tensile small scale specimen with ring-shaped crack.

NeelakanthaV Londe [11] determined the fracture toughness of metallic material by using CCRB specimen having notch angle $\left(45^{\circ}\right)$ and unchanged outer diameter (D) with different notch diameter (d) of Al6082-T6 alloy. They have found the value of $\mathrm{K}_{\mathrm{IC}}$ closer to standard tests.

Ali Bayram [8] determine the fracture toughness of metallic material using CCRB specimen having notch angle $\left(60^{\circ}\right)$ and unchanged outer diameter (D) with different notch diameter (d) tested for different metallic materials also find 
the fracture toughness by adding the correction factor. They have concluded that fracture toughness measurement of metallic material using CCRB specimen is to be an accurate and reliable procedure.

S K Nath [1] determine the fracture toughness of medium carbon steel using CCRB specimen having different notch angles i.e. $45^{\circ}, 60^{0}, 75^{\circ}$ and unchanged specimen diameter (D) with different notch diameter(d). They have tested the material before heat treatment and after heat treatment and concluded that samples with lower notch diameter shows higher $\mathrm{K}_{\mathrm{IC}}$ for same notch angle as compared to higher notch diameter.

The objective of the present work is to determine the effect of specimen diameter (D) and notch diameter (d) on fracture toughness and to validate the results with the standards. For the present study the ratio of D/d kept as constant and the ratio is equal to 1.2 with same notch angles. Also the effect of constant $\mathrm{D} / \mathrm{d}$ ratio with different notch angles on fracture toughness value by using CCRB specimen is investigated.

\section{THEORETICAL BACKGROUND}

The determination of fracture toughness is based on the stress intensity factor $\left(\mathrm{K}_{\mathrm{IC}}\right)$ at the crack tip, where I- denotes that the fracture toughness test is performed in tensile mode and $\mathrm{C}$ - denotes that the value of $\mathrm{k}$ is critical. Unstable crack propagation occurs when $\mathrm{K}$ attains a critical value and the component fails. In Linear Elastic Fracture Mechanics (LEFM) the critical Stress Intensity Factor (SIF) characterizes the fracture toughness [12].

Wang. C.H et al. [13] have given an equation for calculating $\mathrm{K}_{\mathrm{IC}}$ of a CCRB specimen under tensile load and is given in equation (1). This relation is valid for $1.2 \leq \mathrm{D} / \mathrm{d} \leq 2.1$.

$$
K_{I C}=\left[0.932 P_{f} \sqrt{ } D\right] /\left(d^{2} \sqrt{ } \pi\right) \quad \ldots \ldots . .(E q 1)
$$

Where, $\mathrm{P}_{\mathrm{f}}$ is the fracture load,

$\mathrm{D}$ is the diameter of the specimen, and $\mathrm{d}$ is the diameter of the notched section Fig-: 1 .

According to Dieter [14] for round notched tensile specimen, fracture toughness $\mathrm{K}_{\mathrm{IC}}$ found using following $\mathrm{Eq}$.

$$
\mathrm{K}_{\mathrm{IC}}=\mathrm{P}_{\mathrm{f}} /(\mathrm{D})^{3 / 2}[1.72(\mathrm{D} / \mathrm{d})-1.27]
$$

Where, $\mathrm{P}_{\mathrm{f}}$ is the fracture load,

$\mathrm{D}$ is the diameter of the specimen, and $\mathrm{d}$ is the diameter of the notched section Fig-:1.

The assumption made while formulating above expression is that the specimen retains its elastic behavior until fracture occurs. This relation is valid for the $\mathrm{D} / \mathrm{d}$ ratio between 1.00 and 1.25 .

\section{MATERIAL SELECTION}

The material used for present work is Al7075 T-6 alloy whose chemical composition is given in Table-: 1 and initially diameter of rod is $16 \mathrm{~mm}$.

Table-: 1 Chemical composition of Al7075 T-6 alloy used, in $\mathrm{wt} \%$.

\begin{tabular}{|l|l|}
\hline Component & Wt. \% \\
\hline $\mathrm{Al}$ & $87.1-91.4$ \\
\hline $\mathrm{Cr}$ & $0.18-0.28$ \\
\hline $\mathrm{Cu}$ & $1.2-2$ \\
\hline $\mathrm{Fe}$ & Max 0.5 \\
\hline $\mathrm{Mg}$ & $2.1-2.9$ \\
\hline $\mathrm{Mn}$ & Max 0.3 \\
\hline $\mathrm{Si}$ & Max 0.4 \\
\hline $\mathrm{Ti}$ & Max 0.2 \\
\hline $\mathrm{Zn}$ & $5.1-6.1$ \\
\hline Other, each & Max 0.05 \\
\hline Other, total & Max 0.15 \\
\hline
\end{tabular}

Table-: 2 Mechanical properties of A17075 T-6 alloy

\begin{tabular}{|l|l|}
\hline Property & Value \\
\hline Ultimate Tensile Strength & $572 \mathrm{MPa}$ \\
\hline $\begin{array}{l}\text { Fracture Toughness }\left(\mathrm{K}_{\mathrm{IC}} \text { in }\right. \\
\text { L-T direction) }\end{array}$ & $29 \mathrm{MPa}-\mathrm{m}^{1 / 2} \mathbf{2}$ \\
\hline $\begin{array}{l}\text { Fracture Toughness }\left(\mathrm{K}_{\mathrm{IC}} \text { in }\right. \\
\text { T-L direction) }\end{array}$ & $25 \mathrm{MPa}-\mathrm{m}^{1 / 2} / 2$ \\
\hline
\end{tabular}

\section{SPECIMEN PREPARETION AND}

\section{EXPERIMENTATION}

\subsection{Specimen Preparations}

The test specimen geometry is as shown in Fig-:1. Nine UTM testing specimens have been prepared as per standard specifications by using conventional lathe machine with following dimensions.

Specimen diameter (D): $12 \mathrm{~mm}, \quad 10 \mathrm{~mm}, \quad 8 \mathrm{~mm} \quad$ (Three different diameters have been used).

Gauge length (Lo): 5D.

Specimen length (L): 30D.

Notch diameter (d):10mm, $8.3 \mathrm{~mm}, 6.7 \mathrm{~mm}$ (Three notch diameters have been used).

Notch angle $(\alpha): 45^{\circ}$ 


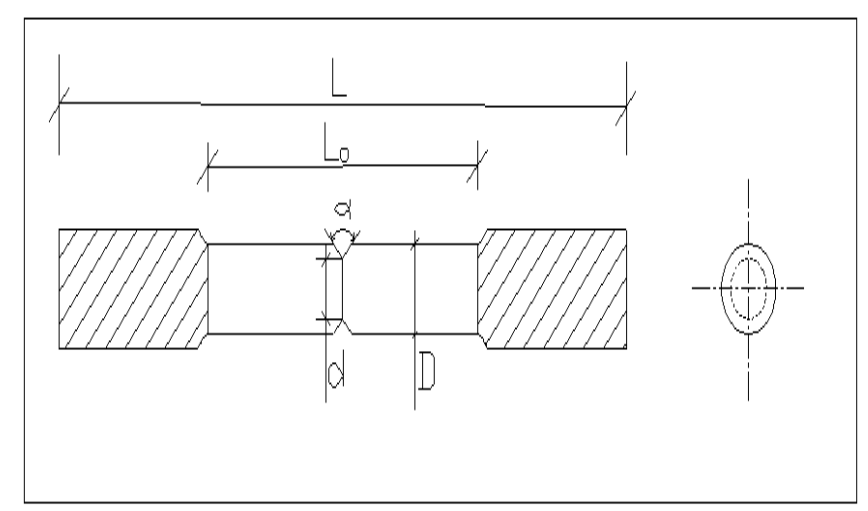

Fig-:1 Schematic representation of round notched tensile specimen

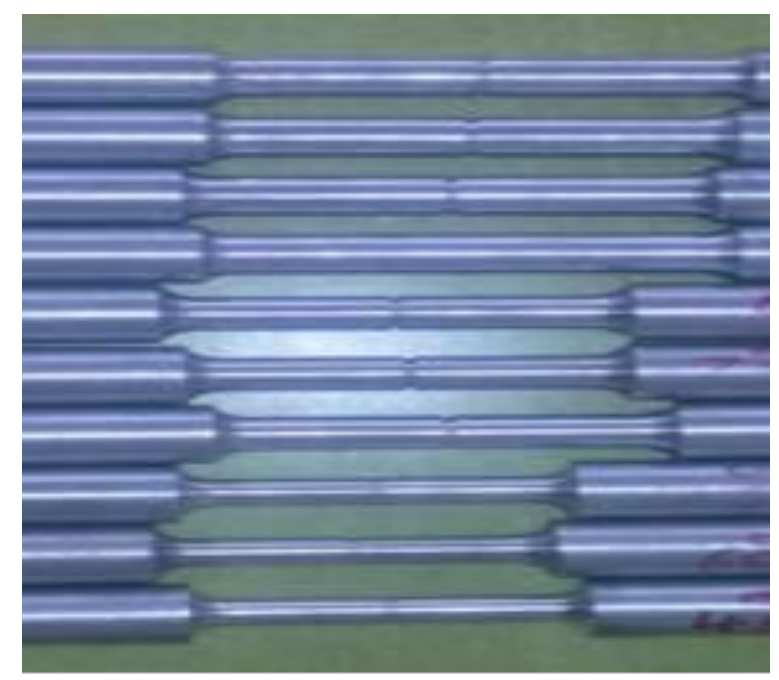

Fig-:2 circumferentially crack round bar testing specimens

\subsection{Experimentation}

The tensile test of each CCRB specimen was performed on $400 \mathrm{KN}$ Universal testing machine at room temperature.

After conducting the experimental work on universal testing machine the Table 6.1 shows that the experimental values of ultimate stress and fracture load of each CCRB specimen.

Table -:3 Details of Ultimate Stress, Fracture load values of various Notch diameters.

\begin{tabular}{|l|l|l|l|l|l|}
\hline $\begin{array}{l}\text { Tria } \\
\text { No. } \\
\text { No }\end{array}$ & $\begin{array}{l}\text { Notch } \\
\text { angle( }\end{array}$ & $\begin{array}{l}\text { Specimen } \\
\text { diameter( } \\
\mathrm{D})\end{array}$ & $\begin{array}{l}\text { Notch } \\
\text { diameter( } \\
\mathrm{d})\end{array}$ & $\begin{array}{l}\text { Ultimat } \\
\mathrm{e} \\
\text { Stress } \\
(\mathrm{MPa})\end{array}$ & $\begin{array}{l}\text { Fractur } \\
\text { e load } \\
\left(\mathrm{P}_{\mathrm{F}}\right) \text { in } \\
\text { KN }\end{array}$ \\
\hline 1 & $45^{0}$ & 08 & 6.7 & 498 & 25.06 \\
\hline 2 & $45^{0}$ & 10 & 8.3 & 461 & 36.20 \\
\hline 3 & $45^{0}$ & 12 & 10 & 428 & 48.42 \\
\hline 4 & $45^{0}$ & 08 & 6.7 & 500 & 25.12 \\
\hline 5 & $45^{0}$ & 10 & 8.3 & 462 & 36.30 \\
\hline 6 & $45^{0}$ & 12 & 10 & 429 & 48.56 \\
\hline 7 & $45^{0}$ & 08 & 6.7 & 499 & 25.10 \\
\hline 8 & $45^{0}$ & 10 & 8.3 & 460 & 36.15 \\
\hline 9 & $45^{0}$ & 12 & 10 & 428 & 48.38 \\
\hline
\end{tabular}

\section{RESULT AND DISCUSSION}

The specimen having different notch angles and different notch diameter as well as specimen diameter was loaded on UTM machine and results are recorded. The measurement of fracture toughness is based on the critical stress intensity factor $\left(\mathrm{K}_{\mathrm{IC}}\right)$ of the test specimen under Mode-I loading condition.

Table-: 3 show the experimental observations of maximum loads and ultimate stresses of each specimen. The planestrain fracture toughness of $\mathrm{Al}$ 7075-T6 alloy tested using CCRB specimen geometry, it was found to be in a range of 26.25 to 28.89 as per Eq. (1) and 27.44 to 29.24 as per Eq. (2) shown in Table-:4. These two equations give $K_{I C}$ value in a valid range as available in the literature using standard CT (Compact Tension) specimens. The notch diameter $6.7 \mathrm{~mm}$ gives fracture toughness lower value and notch diameter $10 \mathrm{~mm}$ gives fracture toughness higher value. It is observed that as minimum notch diameter gives minimum value of $\mathrm{K}_{\mathrm{IC}}$ and as higher notch diameter gives maximum value of $\mathrm{K}_{\mathrm{IC}}$.

Table-:4 Details of Fracture Toughness $\left(\mathrm{K}_{\mathrm{IC}}\right)$ values of notch angle with different diameters as per Eq.1 and Eq.2.

\begin{tabular}{|c|c|c|c|c|c|}
\hline \multirow[t]{2}{*}{$\begin{array}{l}\text { Trial } \\
\text { No. }\end{array}$} & \multirow{2}{*}{$\begin{array}{l}\text { Notch } \\
\text { angle } \\
(\alpha)\end{array}$} & \multirow{2}{*}{$\begin{array}{l}\text { Specim } \\
\text { en } \\
\text { Diamet } \\
\text { er } \\
\text { (D) }\end{array}$} & \multirow{2}{*}{$\begin{array}{l}\text { Notch } \\
\text { diamet } \\
\text { er } \\
\text { (d) }\end{array}$} & \multicolumn{2}{|c|}{$\begin{array}{l}\text { Fracture Toughness } \\
\mathrm{K}_{\mathrm{IC}}(\mathrm{MPa} \sqrt{m})\end{array}$} \\
\hline & & & & Eq 1 & $\mathrm{Eq} 2$ \\
\hline 1 & $45^{0}$ & 08 & 6.7 & 26.25 & 27.44 \\
\hline 2 & $45^{0}$ & 10 & 8.3 & 27.63 & 29.04 \\
\hline 3 & $45^{0}$ & 12 & 10 & 27.89 & 29.24 \\
\hline 4 & $45^{\circ}$ & 08 & 6.7 & 26.31 & 27.51 \\
\hline 5 & $45^{0}$ & 10 & 8.3 & 27.70 & 29.12 \\
\hline 6 & $45^{0}$ & 12 & 10 & 27.97 & 29.33 \\
\hline 7 & $45^{0}$ & 08 & 6.7 & 26.29 & 27.49 \\
\hline 8 & $45^{0}$ & 10 & 8.3 & 27.60 & 29.00 \\
\hline 9 & $45^{0}$ & 12 & 10 & 27.86 & 29.22 \\
\hline
\end{tabular}

Table -:5 Details of Ultimate stress of different notch

\begin{tabular}{|l|l|l|l|l|}
\hline $\begin{array}{l}\text { Trial } \\
\text { No. }\end{array}$ & $\begin{array}{l}\text { Notch } \\
\text { angle } \\
(\alpha)\end{array}$ & $\begin{array}{l}\text { Specime } \\
\mathrm{n} \\
\text { diameter } \\
(\mathrm{D})\end{array}$ & $\begin{array}{l}\text { Notch } \\
\text { diame } \\
\text { ter(d) }\end{array}$ & $\begin{array}{l}\text { Ultimate } \\
\text { Stress } \\
(\mathrm{MPa})\end{array}$ \\
\hline 1 & $45^{0}$ & 8 & 6.7 & 498 \\
\hline 2 & $45^{0}$ & 10 & 8.3 & 461 \\
\hline 3 & $45^{0}$ & 12 & 10 & 428 \\
\hline
\end{tabular}

Table -: 5 Shows that after introducing notch to the testing specimen the properties of material are changes and it is observed that as notch diameter and specimen diameter increases the ultimate tensile strength of material decreases. 


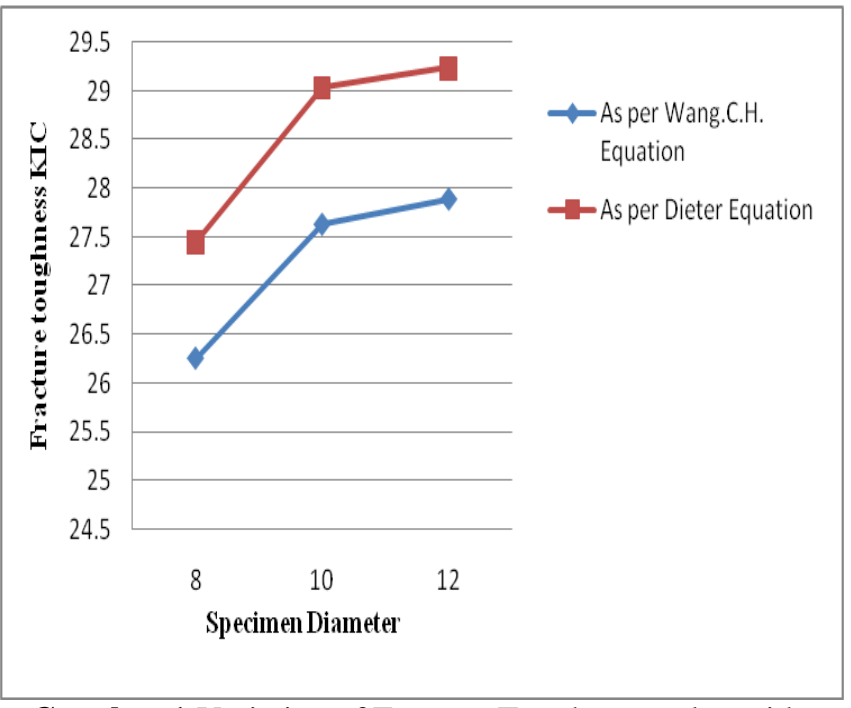

Graph -: 1 Variation of Fracture Toughness value with notch diameter using Wang.C.H. Equation and Dieter Equation

Graph- :1 shows that with same notch angle and constant $\mathrm{D} / \mathrm{d}$ ratio, as increasing specimen diameter along with notch diameter the values of fracture toughness get increases.

\section{CONCLUSION}

- $\quad$ Fracture toughness $\left(\mathrm{K}_{\mathrm{IC}}\right)$ of metallic material can be successfully determined by using round bar tensile specimen and the obtained results are found to be in good agreement with other results obtained from compression tension (CT) specimens.

- $\quad$ The plane-strain fracture toughness of Al 7075-T6 alloy tested using CCRB specimen geometry was found to be in a range of 26.25 to 28.89 as per Eq. (1) and 27.44 to 29.24 as per Eq. (2) which is valid range of $\mathrm{K}_{\mathrm{IC}}$ for A17075-T6 as available in literature obtained by standard tests.

- It was observed that the value of notch diameter and specimen diameter changes the values of $\mathrm{K}_{\mathrm{IC}}$.

- The value of fracture toughness is lower for $8 \mathrm{~mm}$ diameter and is higher for $10 \mathrm{~mm}$ diameter.

- The result shows that as increasing specimen diameter along with notch diameter the values of fracture toughness get increases.

- It is observed that as specimen diameter along with notch diameter increases the ultimate tensile strength of material get decreases.

- It has been observed that the presence of notch decreases the \% elongation of the material specimen.

- $\quad$ The presence of notch in tensile test specimen causes brittle failure although the material is ductile.

\section{REFERENCES}

[1]. S.K. Nath and Uttam Kr Das: Effect of microstructure and notches on the fracture toughness of medium carbon steel, Journal of Novel Architecture and Marine Engineering June, 2006.
[2]. Anon: ASTM Designation E399, Standard Test Method for Plane-Strain Fracture Toughness of Metallic Materials in Annual Book ofASTM Standards, Part 3, American Society for Testing and Materials,Philadelphia, PA, 1988, pp. 680-715.

[3]. S. Kang and N.J. Grant: Notch Tensile Testing as a Measure of the Toughness of Aluminum Alloys, Mat. Sci. Eng., 1985, 72, pp. 155-62.

[4]. K. Kobayashi, H. Imada, and T. Majima: Nucleation and Growth ofCreep Voids in Circumferentially Notched Specimens," JSME Int.J.A.-Solid M., 1998, 41, pp. 218-24.

[5]. A. Valiente and J. Lapena: Measurement of the Yield and TensileStrengths of Neutron-Irradiated and PostIrradiation Recovered VesselSteels with Notched Specimens,Nucl. Eng. Des, 1996, 167(1), pp.11-22.

[6]. D.M. Li and A. Bakker: Fracture Toughness Evaluation for an RSPAl Alloy Using Circumferentially-Cracked Cylindrical Bar Specimens, Eng. Fract. Mech., 1997, 57, pp. $1-11$.

[7]. B. Ule, B. Leskocsek, and B. Tuma: Estimation of Plane Strain FractureToughness of AISI M2 Steel FromPrecracked Round-Bar Specimens, Eng. Fract. Mech., 2000, 65, pp. 559-72.

[8]. AliBayram;AgahUguz; Ali Durmus.(2002):Rapid determination of the fracture toughness of metallic materials using circumferentially notched bars. J. Mater. Eng. Perform. 11(5), pp, 571-576.

[9]. Christopher D. Wilson; John D. Landes. (2000): Fracture toughness testing with notched round bars. Fatigue and Fracture Mechanics 30, ASTM STP 1360, pp.69-82.

[10]. Wang Chang. (1987): Measurement of fracture toughness KIC by single small-scale cylindrical specimen with ring-shaped crack. EFM,28(3), pp.241-250.

[11]. Neelakantha V Londe: Use of round bar specimen in fracture toughness test of metallic materials, International Journal Of Engineering Science and Technology Vol.2(9),2010,4130-4136.

[12]. Marc Scibetta; RachidChaouadi; E.VanWalle. (2000): Fracture toughness analysis of circumferentially cracked bars. Int. J Fract., 104,pp.145-168

[13].Wang.C.H.(1996):Introduction to Fracture Mechanics; Stress analysis of cracked bodies. Aeronautical and Maritime Research Laboratory.Victoria 3001, Melbourne, DSTO-GD-0103, pp.10-28.

[14]. Dieter, G. E. (1988): Mechanical Metallurgy, SI ed., McGraw-Hill, Singapore, pp.348-368.

\section{BIOGRAPHIES}

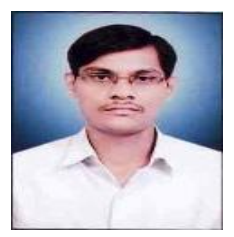

Mr. Trimbak K. Todkari (Student of M.E. Machine Design), M.E. Machine Design Student, Mechanical Department, M. S. Bidve Engineering College, Latur, Maharashtra, India 
Prof. M.C.Swami, Assistant Professor, Mechanical Department, M. S. Bidve Engineering College, Latur, Maharashtra, India

Prof. P.S.Patil, Assistant professor, Mechanical Department, G. N. D. Engineering College, Bidar, Karnataka, India. 